\title{
Some vegetation responses to selected livestock grazing strategies, Edwards Plateau, Texas
}

THOMAS L. THUROW, WILBERT H. BLACKBURN, AND CHARLES A. TAYLOR, JR.

\section{Abstract}

Understanding the temporal response of vegetation to selected livestock grazing strategies is necessary for the continued maintenance or increased productivity of rangelands. Vegetation cover and above-ground biomass were sampled bimonthly from 1978-1984 on pastures grazed continuously (MCG) and moderately stocked (8.1 ha AU-1); continuously (HCG) and heavily stocked (4.6 ha AU-1); high-intensity, low-frequency (HILF) and moderately stocked (8-1; 17:119 day stocked at 8.1 ha AU-); short-duration grazing (SDG) and heavily stocked (14-1; 4:50 day, stocked at 4.6 ha AU-1); and livestock exclusion (LEX). Prior grazing history, vegetation cover, soils, and slope were similar among pastures. Midgrass cover was eliminated in the HCG pasture, and declined in the heavily stocked SDG pasture. Midgrass cover was maintained under the moderately stocked HILF grazing strategy and increased under MCG or LEX. During 1984, sideosts grama (Bouteloua curtipendula (Michx.) Torr.) basal diameter in the MCG and LEX pastures was significantly greater than in the SDG pasture. By the end of the study, total organic cover and total aboveground biomass in the MCG or LEX pastures were significantly greater than in the SDG and HCG pastures. The heavy grazing intensity used in this study, regardless of the grazing strategy, does not appear suited for long-term maintenance of midgrass species.

Key Words: vegetation cover, aboveground biomass, bunchgrass, sodgrass

Rangeland vegetation is presumed to have co-evolved with grazing animals, and as a result most rangeland vegetation possesses some level of grazing tolerance (Mack and Thompson 1982). The magnitude of impact that livestock grazing may have on a plant community is theretore dependent upon intensity of grazing. Grazing schemes can be divided into 2 broad categories: (1) continuous year-long or season-long grazing; and (2) periodic grazing. Grazing systems are included in the latter because they are defined as systematically recurring periods of grazing and deferment for 2 or more pastures or management units (Kothmann 1974).

Vegetation composition is used as an indicator of range condition. Ellison (1960) concluded that successional trends in plant communities are proportional to grazing intensity, with most severe changes occurring under heavy grazing. Heavy grazing pressure tends to damage the most palatable species and reduce their abundance (Dyksterhuis 1949, Cottam and Evans 1945). Loss of preferred species is usually associated with a decline in the nutritional value of the available forage and a decline in available forage (Boudet 1975). Compositional shifts in perennial plants are espe-

\footnotetext{
Authors are currently range research scientist, Louis Berger International, P.O. Box 2954, Mogadishu, Somalia; hydrologist, USDA-Agricultural Research Service, Northwest Watershed Research Center, 270 South Orchard, Boise, Ida. 83705; and superintendent of the Texas Agricultural Experiment Station at Sonora 76950. At the time of this research the senior and second authors were graduate research assistant and professor of watershed management at Texas A\&M University, respectively.

This study was a cooperative project between the U.S. Department of Agriculture and Texas Agricultural Experiment Station. Financial support of the Soil Conservation Service RCA Special Study and a Science/Education Grant is acknowledged. The assistance of H.D. Petersen, statistician, USDA-Agricultural Research Service, College Station, Texas, with the experimental design and statistical analysis is acknowledged along with the data collection efforts of Robert Knight (1978-1979) and George McCalla (1980-1981). Special thanks to S.L. Hennefer for typing the manuscript.

Published with the approval of the Director, Texas Agricultural Experiment Station as TA-22464, and USDA-Agricultural Research Service, Pacific West Area.

Manuscript accepted 4 November 1987.
}

cially important indicators of range condition because their decline is usually associated with increased erosion hazard (Walker 1974). It has been shown generally that as grazing intensity increases, vegetation composition shifts from a midgrass to shortgrass dominance (Rhoades et al. 1964, Sharp et al. 1964, Wood and Blackburn 1984). These shifts in composition have been shown generally to result in a reduction in water infiltration rates and accelerated soil erosion which, ultimately reduces the long-term productivity of rangelands (Thurow 1985; McCalla et al. 1984a, 1984b; Blackburn 1984). The objective of this study was to assess the temporal response of some vegetation variables to selected livestock grazing strategies.

\section{Materials and Methods}

\section{Study Area and Treatments}

Research was conducted at the Texas Agricultural Experiment Station, which is located in Edwards'and Sutton counties $\left(31^{\circ} \mathrm{N}\right.$; $100^{\circ} \mathrm{W}$ ) approximately $56 \mathrm{~km}$ south of Sonora, at an elevation of $632 \mathrm{~m}$. The mean frost-free period is 240 days. Annual precipitation at the station is highly variable in amount (annual median precipitation, $1918-1984=438 \mathrm{~mm}$; range $=156$ to $1,054 \mathrm{~mm}$ ) and events vary seasonally. Cool-season precipitation (October-April) is generally the result of frontal storms characterized by slow, steady rainfall. During the warm season (May-September), most precipitation events are brief, intense convective storms. During this study (1978-1984), an average of 13 storms (range 6-17) with rainfall of $5 \mathrm{~mm}$ or more per storm occurred during the 7 warm seasons. These storms accounted for $92 \%$ (range $87 \%$ to $95 \%$ ) of the warm-season rainfall. In general, March-July 1978 and AprilAugust 1980 were periods of drought and September 1980 through August 1982 was a period of well-distributed, greater than median precipitation (Fig. 1). In 1978 only $24 \mathrm{~mm}$ of rain fell from February 18 to May 19 and no rain fell during the periods of June 8 to July 27 and August 8 to August 28. In 1980 only $6 \mathrm{~mm}$ of rain fell from June 11 to August 8. The stress on plants was further intensified during this period by 49 consecutive days with maximum temperatures of $35^{\circ} \mathrm{C}$ or greater.

During January 1978, three 6-ha study pastures were established by subdividing a larger pasture that had been stocked at a moderate continuous rate of about 8.1 ha $\mathrm{AU}^{-1}$ since 1949. Treatments established were: (1) a continuously grazed (MCG) strategy moderately stocked at 8.1 ha $\mathrm{AU}^{-1}$; (2) a continuously grazed (HCG) strategy heavily stocked at $4.6 \mathrm{ha} \mathrm{AU}^{-1}$; and (3) a high-intensity, low-frequency (HILF) pasture used to simulate an 8 pasture rotation grazing strategy $(8-1 ; 17: 119$ day) moderately stocked at 8.1 ha $\mathrm{AU}^{-\mathrm{P}}$. During January 1980, the HILF strategy pasture was changed to a short duration grazing strategy (SDG) (14-1; 4:50 day) and stocked heavily at $4.6 \mathrm{ha} \mathrm{AU}^{-1}$. Even though the stocking rates were similar in the HCG and SDG pastures, grazing pressure index was greater in the SDG pasture. An animal unit ratio of 50\% cattle, $25 \%$ sheep, and $25 \%$ goats was used on the HILF/SDG and HCG pastures. Due to the small pasture size, the 50:25:25 grazing ratio could not be precisely maintained in the MCG pasture. Sheep and goats were grazed continuously with a cow grazed intermittently to maintain the moderate stocking rate.

In January 1980, a 3 ha livestock exclosure (LEX) was established adjacent to the 3 grazing treatment pastures. This site shared 


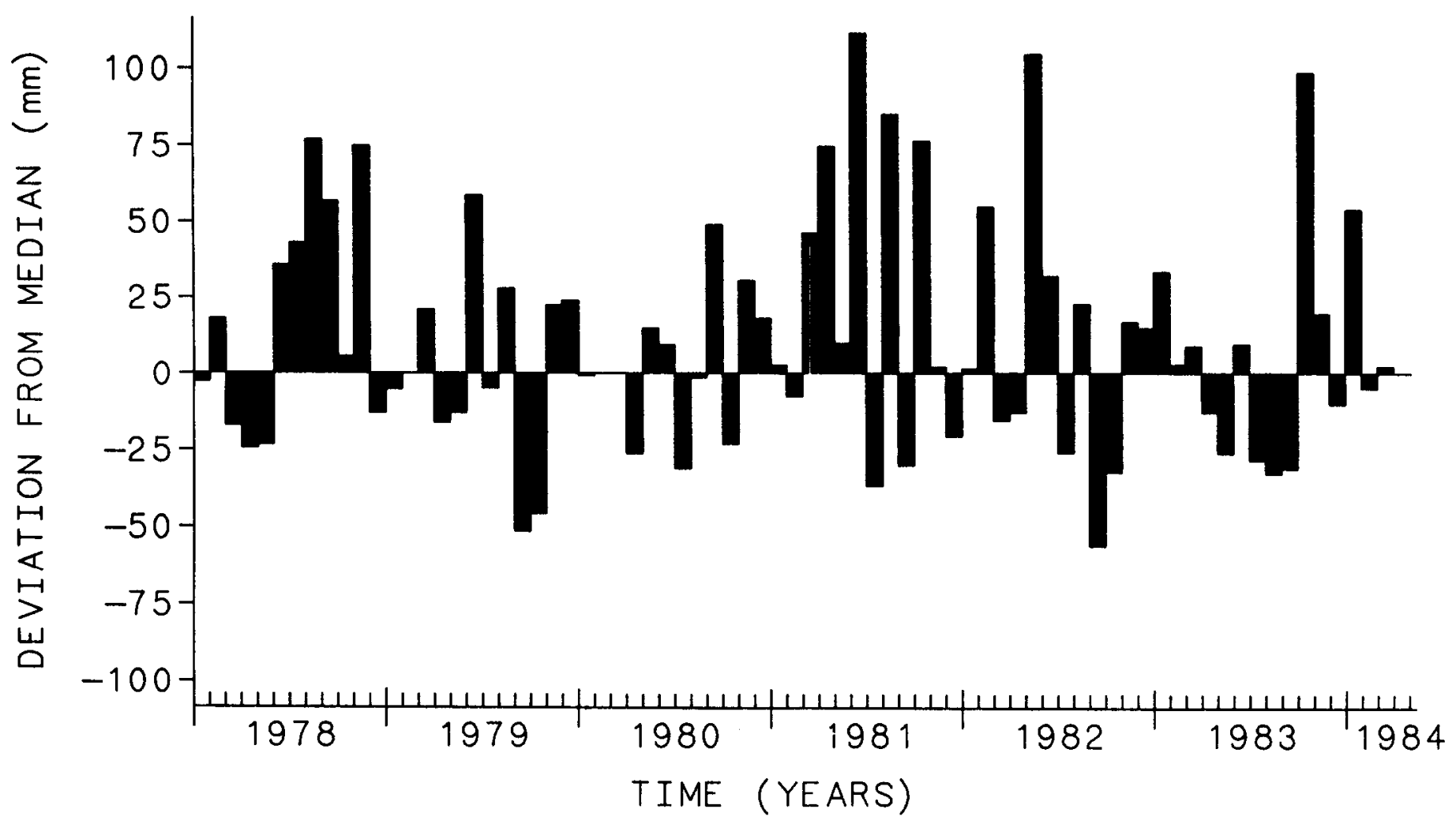

Fig. 1. Deviation from monthly median precipitation during the study period on the Edwards Plateau, Texas. The monthly precipitation median is based on the 67-period of 1981-1984.

the same grazing history of the MCG, HCG, and HILF/SDG pastures prior to 1978. However, in 1978 and 1979, the LEX site was grazed at a rate of about $6 \mathrm{ha} \mathrm{AU^{-1 }}$. Consequently, vegetation trend in the LEX pasture in 1980 was down compared to when the MCG, HCG, and HILF/SDG pastures were established in 1978. The LEX pasture was located on a site with a clayey loam soil that had a higher sand content and greater slope than the other 3 pastures.

Soils in the study pastures were Tarrant silty clays and soil depth overlaying a fracture limestone substrate ranged from about 150 to $450 \mathrm{~mm}$. Textures of this clayey-skeletal, montmorillonitic, thermic family of Lithic Haplustalls ranged from silty clay loam to clay. There was no consistent mean textural difference between the soils of the SDG/HILF, MCG, and HCG pastures. The surface soils of the LEX pasture had lower clay and higher sand content than the other 3 pastures. There was no detectable change in soil texture in any pasture during the study period.

The vegetation in the pastures is characterized as an oakgrassland community (Smeins et al. 1976, Huston et al. 1981). Woody plant distribution was clustered with the dominant species being live oak (Quercus virginiana Mill.). The most common midgrasses were sideoats grama (Bouteloua curtipendula (Michx.) Torr.), Texas wintergrass (Stipa leucotricha Trin. and Rupr.), and threeawn (Aristida spp.). Dominant shortgrasses were curlymesquite (Hilaria belangeri (Steud.) Nash) and hairy grama (Bouteloua hirsuta Lag.).

\section{Methods}

Basal and aerial cover characteristics, herbaceous standing crops, and mulch accumulation were estimated bimonthly in the grazed pastures from March 1978 through 1984, and every 4 months from May 1980 to March 1984 in the LEX pasture. Sample locations were randomly assigned to gridded areas within each pasture prior to initiating the grazing strategies. During each sample period, ten $0.45-\mathrm{m}^{2}$ plots were randomly assigned to midgrass and shortgrass strata within the gridded area. This sampling procedure prevented the destructive sampling of any site more than once during the study. Areas adjacent to fences and watering locations were excluded to avoid differential livestock use patterns associated with these structures. Due to scarcity of midgrass plants in the HCG pasture, sampling of those plants was discontinued after May 1980. For each plot the percent foliar cover of midgrass, shortgrass, forbs, litter, rock (>5 mm), and bare ground was determined by ocular estimate using a 4-cm gridded frame. Standing crop of grasses and forbs was harvested by clipping. Mulch accumulation was harvested by hand following clipping. All organic material was dried at $60^{\circ} \mathrm{C}$ prior to weighing.

Surface roughness of each plot was measured with a relief meter (a frame with a set of 10 pins placed $60 \mathrm{~mm}$ apart) (Kincaid and Williams 1966). A representative surface roughness index was obtained by measuring the relief of 3 different lines across each plot and then calculating the standard deviation of the pin height.

In addition to the destructive sampling technique described above, 9 permanent $0.25-\mathrm{m}^{2}$ vegetation plots were established in each pasture during August 1980. A 10-point frame (Brown 1954) was used bimonthly to measure canopy and basal cover on these plots. A total of 250 canopy points and 250 basal points were recorded for each pasture. Vegetation cover was also estimated on a pasture-wide basis using the step-point method. Five hundred points in each pasture were sampled once each August from 1978 through 1984. In September 1984, basal diameter and standing biomass estimates were made in each pasture from 50 randomly chosen sideoats grama bunches, and area clump diameter was made of 50 randomly chosen sacahuista (Nolina texana S. Wats.) bunches. Meteorological data were collected at a permanent station located $1 \mathrm{~km}$ from the study pastures.

\section{Analyses}

Data normality was tested for skewness and kurtosis (Snedecor and Cochran 1971). Because values for surface roughness were 


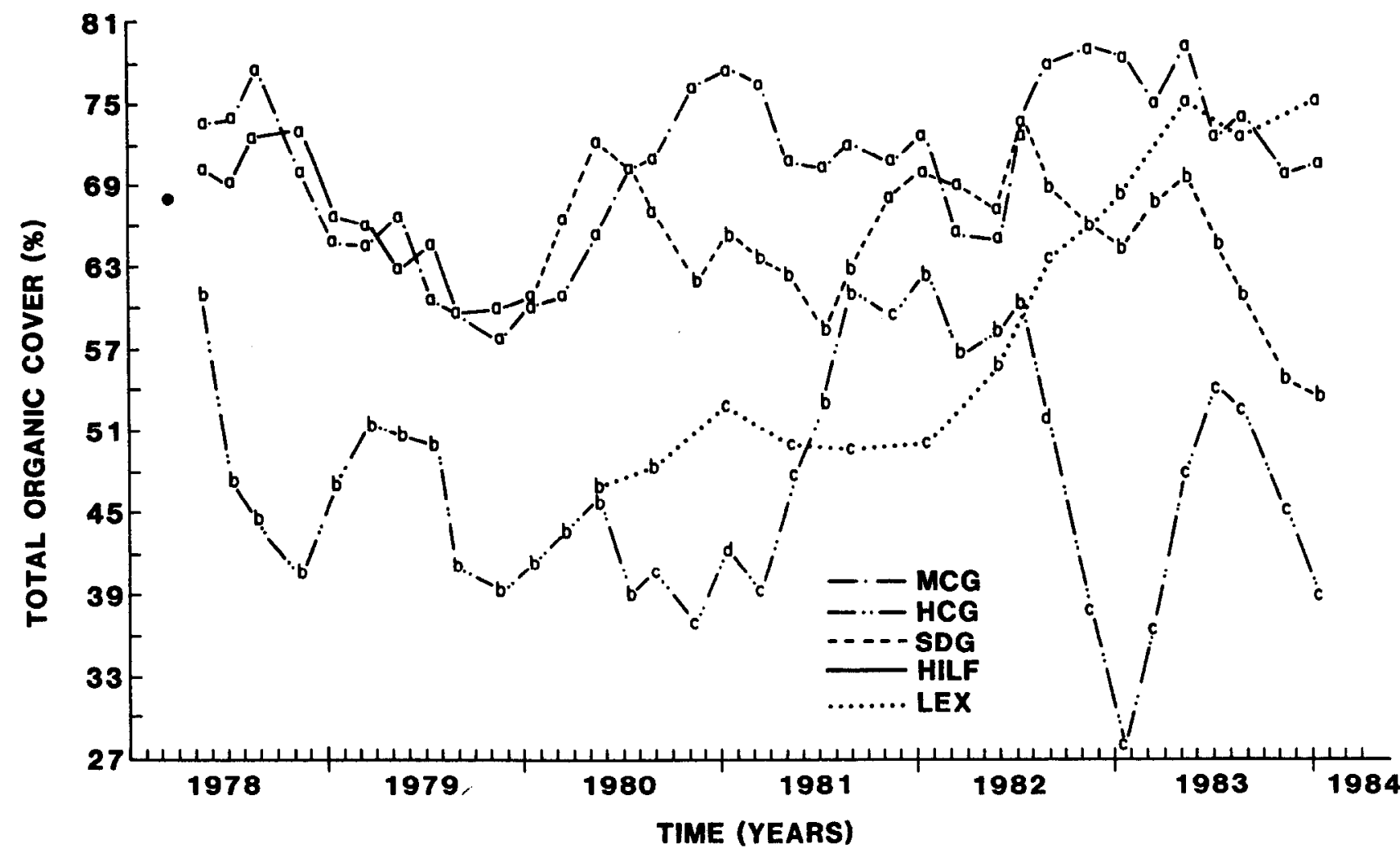

Fig. 2. Total organic cover (\%) as estimated on the $0.45 \mathrm{~m}^{2}$ plots, Edwards Plateau, Texas. Grazing treatment means with the same letter for the same sample date are not significantly different ( $<<0.05$ ). The dot indicates the composite sample value for March 1978.

highly skewed, they were transformed using $\log _{10}$ before analyses. Differences among vegetation communities and grazing strategy were tested by analysis of variance. Grazing strategies were not replicated and the error term in the analysis of variance consisted of the nested variation of the randomized sites within the grazing strategies (Dunn and Clark 1974). Treatment means were separated by Duncan's new multiple-range test (Duncan 1955). Correlation analysis (Draper and Smith 1981) was used to assess magnitude of linear association among variables.

Figures 2, 3, 4 and 6 display running averages of 3 sample dates. This procedure aided in graphic display of long-term trends by smoothing variation of individual sample dates that might have resulted from natural site diversity. Data were graphed as weighted composite of the midgrass-and shortgrass-dominated plots. The composite was formed by weighting the percentage of midgrassand shortgrass-dominated areas in each pasture using the data from the pasture-wide step-point transects. The percentage of midgrass- and shortgrass-dominated areas was updated by treatment on a March to March basis.

\section{Results}

\section{Vegetation Cover}

Warm-season grasses dominated the study area; therefore, cover began to increase with the onset of the spring growing season. Total organic cover (percent ground cover provided by living and dead organic matter) (Fig. 2) generally continued to increase until mid-summer after which declining soil moisture presumably began to limit growth. The same general pattern was observed for organic basal cover (Thurow 1985). Total organic cover was significantly greater on midgrass-dominated sites (mean total organic cover of 72\%) compared to shortgrass sites (mean total organic cover of 59\%). Total organic cover of the MCG pasture was less variable than the other grazing strategies during the study. This contrasts with the rapid decline in total organic cover after the HCG strategy was established. Total organic cover of the SDG pasture declined significantly relative to the MCG pasture during the 1980 drought. This difference was maintained throughout most of the remaining 3 years of data collection except during the unusually moist spring of 1982, which prompted rapid forb and shortgrass growth. Total organic cover of the LEX pasture generally increased after the exclosure was established.

Forb cover was dominated by opportunistic, cool-season species. The greatest peaks of forb cover occurred during the cool season following the 1978 and 1980 drought (Fig. 3). In both cases the combined effects of livestock grazing and drought had increased the percentage of bare ground. Bitterweed (Hymenoxys odorata D.C.) was the primary species to revegetate the bare areas in the cool season following droughts.

The patterns of midgrass foliar cover and relative dominance were comparable under the MCG and HILF strategies (Figs. 4 \& 5). Midgrass foliar cover was essentially eliminated during the first 2.5 years under the HCG strategy. Midgrass foliar cover and relative dominance in the heavily stocked SDG pasture was reduced by approximately one-half from 1980 to 1984 and the trend was definitely downward, even after above-normal rains in 1982. During this same 4-year period, midgrass dominance increased in the LEX pasture. These trends were verified by the statistically similar $(P<0.05)$ results obtained on a permanent transect and the step-point transects (Fig. 5). In general, a decline of midgrass relative dominance and an increase in shortgrass dominance was usually associated with heavy livestock grazing and drought. In subsequent years of average or above-average precipitation, midgrass foliar cover increased in the MCG, HILF, and LEX pastures, but vegetation recovery in the SDG and HCG pastures was by shortgrass not midgrass.

Hairy grama and curleymesquite were co-dominant shortgrasses in the LEX pasture, whereas curlymesquite dominated the shortgrass areas in the grazed pastures. Hairy grama, a sod-forming shortgrass, was usually associated with stony-loamy clay soils. The 


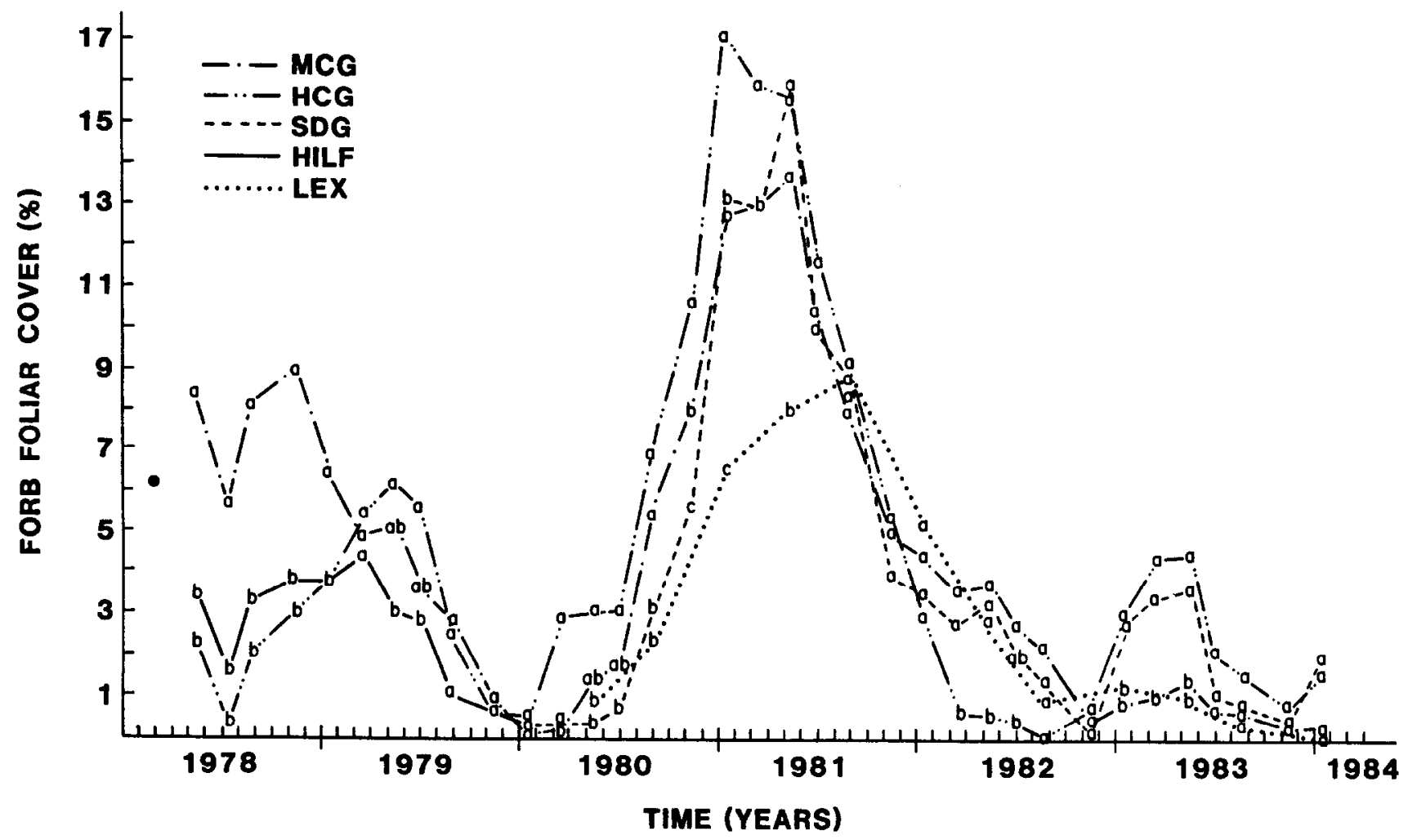

Fig. 3. Forb foliar cover (\%) as estimated on the 0.45- $\mathrm{m}^{2}$ plots, Edwards Plateau, Texas. Grazing treatment means with the same letter for the same sample date are not significantly different $(\mathrm{p}<0.05$ ). The dot indicates the composite sample value for March 1978.

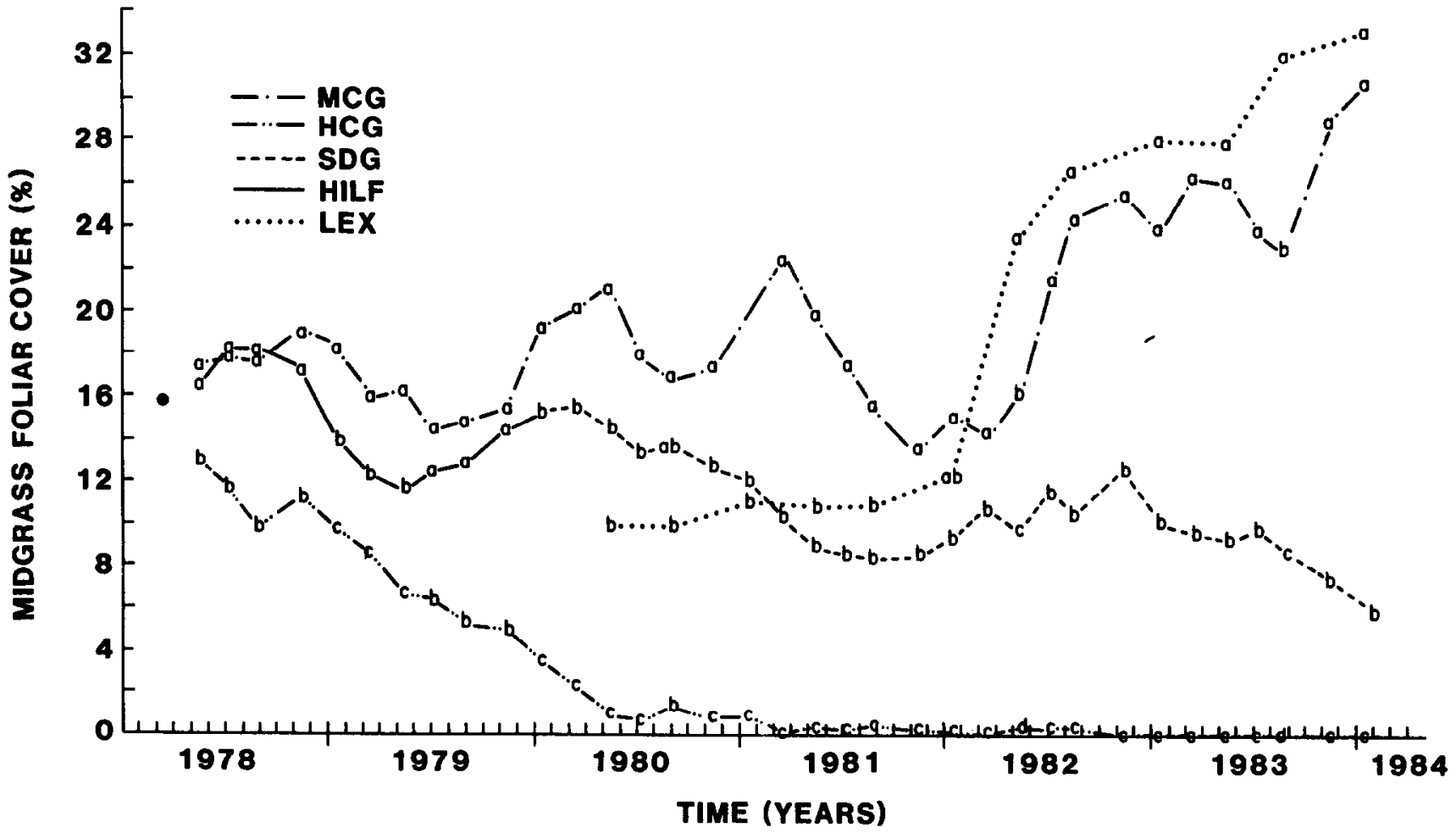

Fls. 4. Midgrass foliar cover (\%) as estimated on the 0.45- $\mathrm{m}^{2}$ plots, Edwards Plateau, Texas. Grazing treatment means with the same letter for the same sample date are not significantly different $(\mathrm{p}<0.05)$. The dot indicates the composite sample value for March 1978. 


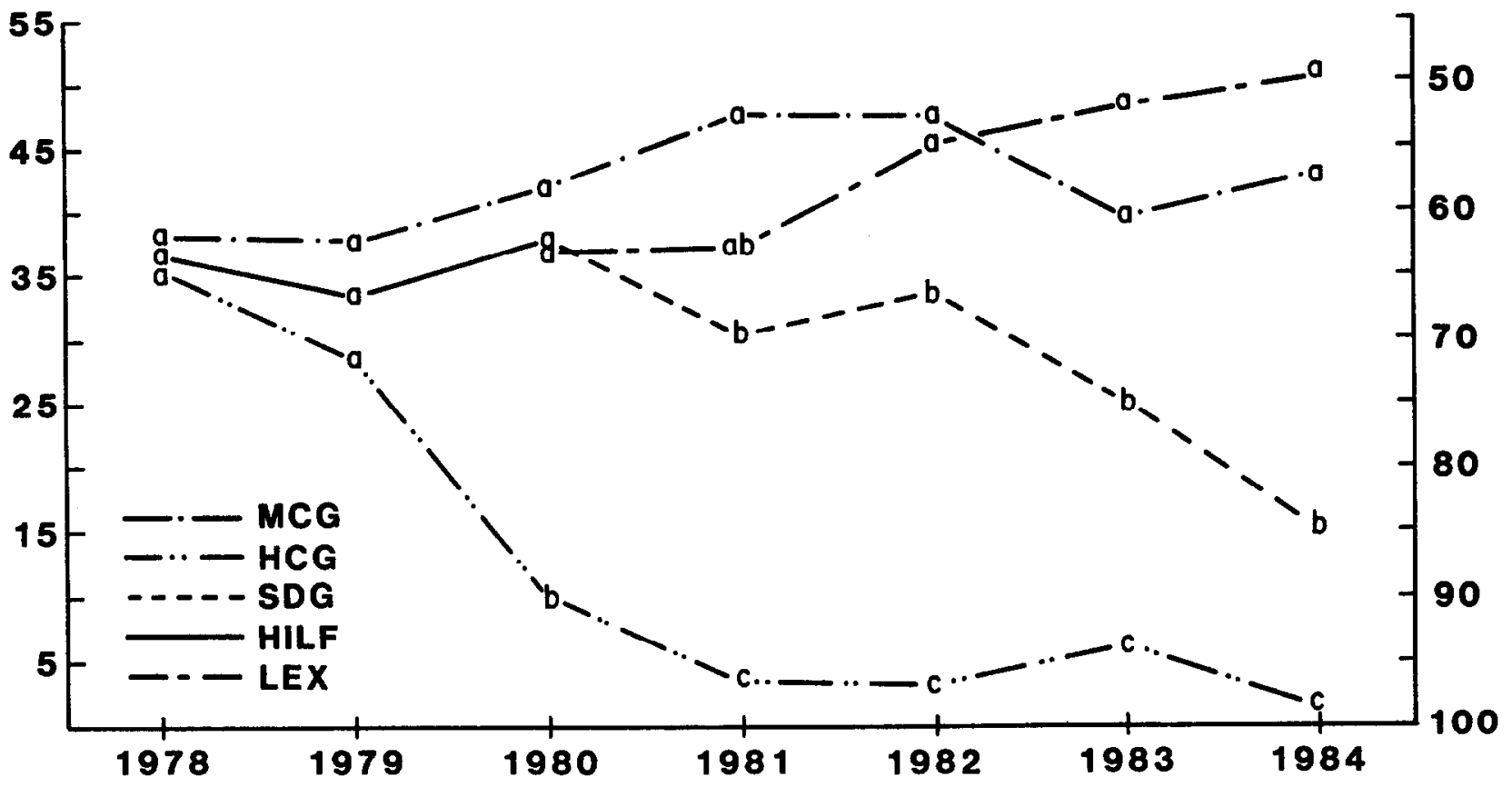

\section{TIME (YEARS)}

Fig. 5. Relative dominance of grass life form as estimated by the step-point method on the Edwards Plateau, Texas. Grazing treatment means with the same letter for the same sample date are not significantly different $(\mathrm{p}<0.05)$.

stony-loamy clay texture of the LEX pasture was in contrast to the stony-clay soils of the HCG, MCG, and HILF/SDG pastures (Thurow 1985).

\section{Above-ground Biomass and Microrelief}

Above-ground biomass declined rapidly under the HCG system and established a new, lower equilibrium that was significantly different from the MCG and HILF pastures (Fig. 6). Aboveground biomass in all pastures declined during the 1978 and 1980 drought. The above-ground biomass of the MCG pasture increased after the 1980 drought and remained significantly greater than that of the SDG and HCG pastures after August 1982. Likewise, aboveground biomass in the LEX pasture steadily increased after the 1980 drought throughout the rest of the study. The above-ground biomass of the SDG pasture was statistically similar to that of the HCG pasture by late 1983.

Basal diameter and standing biomass of sideoats grama bunchgrass clumps were not significantly different in the LEX and MCG pastures, but both were significantly greater than in the SDG pasture (Table 1). Sideoats grama had been eliminated in the HCG pasture. Sacahuista aerial cover diameters were similar in the LEX and MCG pastures, which were both significantly greater than those in SDG and HCG pastures.

The bunchgrass growth form which characterized midgrass cover strongly influenced pasture microrelief $(r=.90)$. However, shortgrass cover was not associated with microrelief $(r=.03)$. Microrelief was consistently greater on midgrass-dominated areas than on shortgrass-dominated areas, primarily because of differences between the bunchgrass and stoloniferous grass growth form.

\section{Discussion and Conclusions}

Cover and above-ground biomass declined during the winter dormant season and during drought for all grazing strategies. The nature of those declines and the ability to recover varied between
Table 1. Characterization of sideoats grama and sacahuista bunches in the continuously grazed moderately stocked (MCG), continuously grazed heavily stocked (HCG), short duration grazed (SDG), and livestock exclosure (LEX) pastures, Edwards Plateau, Texas (September 1984).

\begin{tabular}{|c|c|c|c|}
\hline \multirow[b]{2}{*}{ Grazing strategy } & \multicolumn{2}{|c|}{ Sideoats grama } & \multirow{2}{*}{$\begin{array}{c}\text { Sacahuista } \\
\text { Mean aerial } \\
\text { clump diameter } \\
(\mathrm{m})\end{array}$} \\
\hline & $\begin{array}{c}\text { Mean } \\
\text { basal diameter } \\
(\mathrm{m})\end{array}$ & $\begin{array}{c}\text { Mean dry } \\
\text { standing biomass } \\
\text { per bunch } \\
\text { (g) }\end{array}$ & \\
\hline $\begin{array}{l}\text { LEX } \\
\text { MCG } \\
\text { SDG } \\
\text { HCG }\end{array}$ & $\begin{array}{l}.37 \mathrm{a}^{1} \\
.39 \mathrm{a}^{2} \\
.30 \mathrm{~b} \\
.2\end{array}$ & $\begin{array}{c}23.1 \mathrm{a} \\
24.5 \mathrm{a} \\
16.2 \mathrm{~b} \\
-\end{array}$ & $\begin{array}{l}5.0 \mathrm{a} \\
5.1 \mathrm{a} \\
2.5 \mathrm{~b} \\
2.1 \mathrm{~b}\end{array}$ \\
\hline
\end{tabular}

'Means within each column followed by the same letter are not significantly different $(p<0.05)$.

2No sideoats grama was present after 7 years of the HCG strategy.

grazing strategy. The HCG and SDG pastures were significantly different from each other and from the MCG and LEX pastures in species composition, basal cover (Thurow 1985), and total organic cover by August 1982. Total organic cover remained fairly constant under the MCG and HILF pastures. The higher stocking rate of the HCG pasture ( 1.75 times the $\mathrm{MCG}$ ) caused a sharp decline in total organic cover which coincided with the 1978 drought. The SDG pasture had significantly lower organic cover than the MCG pasture during periods of lower than normal precipitation. The LEX pasture cover did not increase during the favorable precipitation year of 1981 . However, a rapid increase in cover began during 1982.

The SDG pasture was stocked at 1.75 times the moderate rate to test the claims that such strategies would increase the primary production of rangelands (Savory 1978, 1979), but there was no 


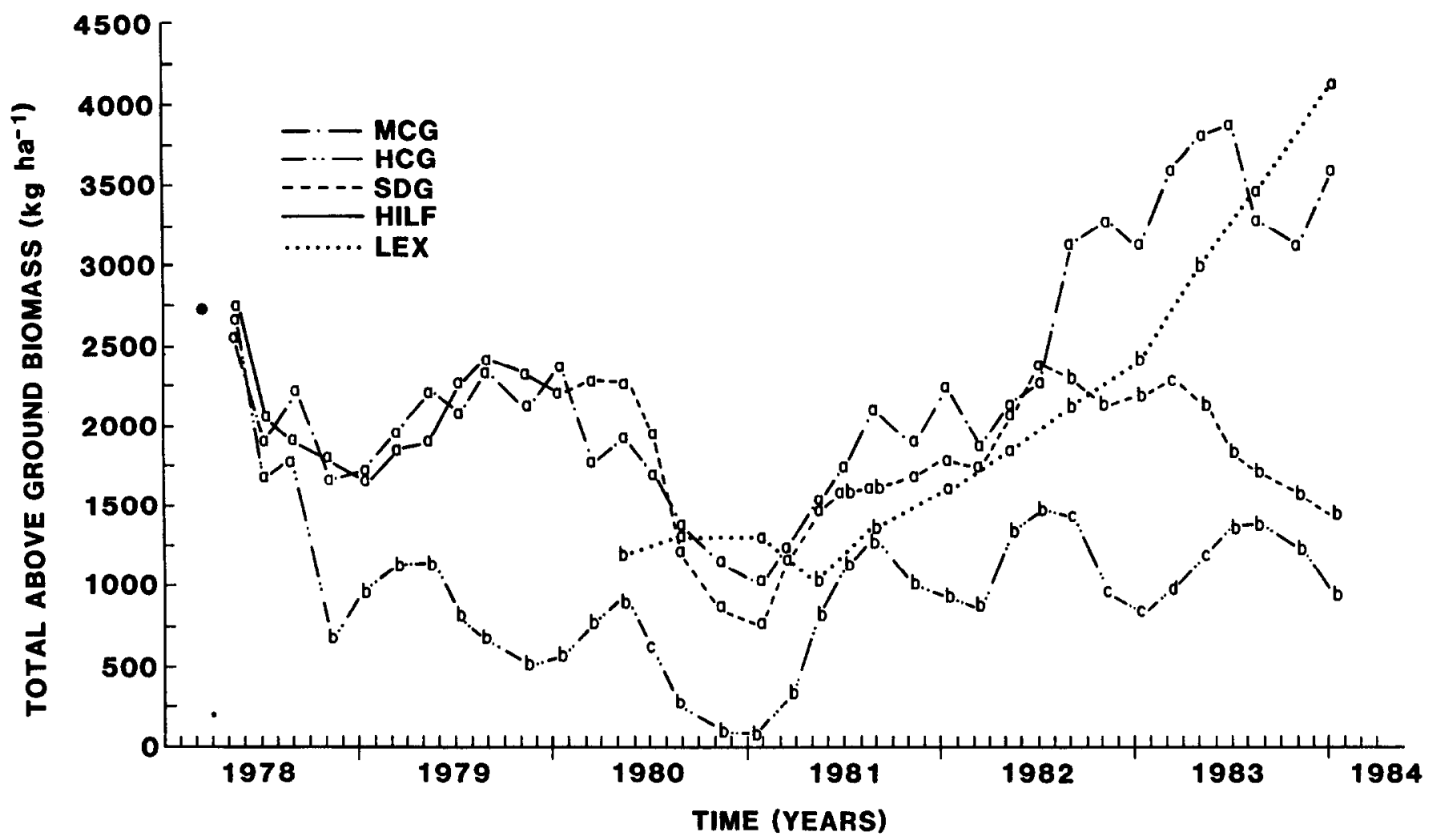

Fig. 6. Total above-ground biomass $\left(\mathrm{kg} \mathrm{ha}^{-1}\right)$ as estimated on the $0.45-\mathrm{m}^{2}$ plots, Edwards Plateau, Texas. Grazing treatment means with the same letter for the sample date are not significantly different $(\mathrm{p}<0.05)$. The dot indicates the composite sample value for March 1978.

evidence of increased production with the higher stocking rates (Ralphs 1983). Such a grazing intensity, regardless of the grazing strategy, does not appear suited for long-term maintenance of the desirable midgrass species. The observed vegetation responses in this study were due primarily to drought and excessive defoliation of individual plants caused by heavy stocking rates regardless of the grazing strategy. However, Ralphs (1983) indicated that under the high stocking density of intensive rotation grazing strategies, midgrasses would not maintain themselves even under light stocking rates. There was a clear decline of midgrass cover in both the SDG and HCG pastures during the study (Figs. 4 and 5). In contrast, there was a slight increase in midgrass cover in the MCG pasture and a marked increase in the LEX. The sharp rise of midgrass cover in the LEX pasture that occurred in 1982 was the result of above-average precipitation in both 1981 and 1982 and protection from livestock grazing. General observation indicated a large bunchgrass seed crop in 1981 was followed by establishment of bunchgrass seedlings in 1982. In contrast, the steady decline of midgrass cover in the SDG and HCG pastures reflected the inability of these species to maintain themselves under the heavier grazing pressure. This shift in species composition affected total cover in that the bunch growth form of the midgrass was much more persistent during the dormant season compared with stoloniferous shortgrass cover, which quickly deteriorated when dormant. This trait of shortgrass cover to rapidly decline during periods of dormancy and rapidly increase during warm, moist periods caused cover and above-ground biomass estimates to seasonally fluctuate in pastures when shortgrass was dominant (e.g., SDG and HCG). Midgrass cover fluctuated relatively little between seasons; therefore, pastures with a well-maintained midgrass component did not show major seasonal fluctuations in total organic cover, biomass, or microrelief. The microrelief caused by bunchgrasses serves as barriers to surface runoff and sediment transport by causing surface runoff to move in a slower, more torturous path. Thus the obstructions provided by the bunch growth form are an important determinant of surface runoff and erosion (Thurow et al. 1986).

\section{Literature Cited}

Blackburn, W.H. 1984. Impacts of grazing intensity and specialized grazing systems on watershed characteristics and responses, p. 927-983. In: Developing Strategies for Rangeland Management. Nat. Res. Council, Nat. Acad. Sci. Westview Press, Boulder, Colo.

Boudet, G. 1975. Pastures and livestock in the Sahel, p. 29-34. In: The Sahel: Ecological Approaches to Land Use. MAB Tech. Notes UNESCO, Paris.

Brown, D. 1954. Methods of surveying and measuring vegetation. Commonwealth Bureau of Pastures and Field Crops. Hurley, England. Bull. 42.

Cottam, W.P., and F.R. Evans. 1945. A comparative study of the vegetation of grazed and ungrazed canyons of the Wasatch Range, Utah. Ecol. 26:171-181.

Draper, N.R., and H. Smith. 1981. Applied regression analysis. John Wiley and Sons, Inc., New York.

Duncan, D.B. 1955. Multiple range and multiple F test. Biom. 11:1-42.

Dunn, O.J., and V.A. Clark. 1974. Applied statistics: Analysis of variance and regression. John Wiley and Sons, Inc., New York.

Dyksterhuis, E.J. 1949. Condition and management of rangeland based on quantitative ecology. J. Range Manage. 2:104-115.

Ellison, L. 1960. Influence of grazing on plant succession of rangelands. Bot. Rev. 26:1-78.

Huston, J.E., B.S. Rector, L.B. Merrill, and B.S. Engdahl. 1981. Nutritional values of range plants in the Edwards Plateau region of Texas. Texas Agr. Exp. Sta., B-1357.

Kincaid, D.R., and G. Williams. 1966. Rainfall effects on soil surface characteristics following range improvements. J. Range Manage. 19:346351.

Kothmann, M.M. 1974. A glossary of terms used in range management. Soc. for Range Manage., Denver, Colo.

Mack, R.N., and J.N. Thompson. 1982. Evolution in steppe with few large hooved mammals. Amer. Natur. 119:757-773.

MeCalla II, G.R., W.H. Blackburn, and L.B. Merrill. 1984a. Effects of livestock grazing on sediment production, Edwards Plateau of Texas. J. Range Manage. 37:291-294. 
McCall II, G.R., W.H. Blackburn, and L.B. Merrill. 1984b. Effects of livestock grazing on infiltration rates, Edwards Plateau of Texas. J. Range Manage. 37:265-269.

Ralphs, M.H. 1983. Vegetation and livestock response to increased stocking rates in a simulated short-duration grazing system. Ph.D. Diss. Texas A\&M Univ., College Station. (Diss. Abstr. 45:21)

Rhoades, E.D., L.F. Locke, H.M. Taylor, and E.H. Mcllvain. 1964. Water intake on a sandy range as affected by 20 years of differential cattle stocking rates. J. Range Manage. 17:185-190.

Savory, A. 1978. A holistic approach to ranch management using short duration grazing, p. 555-557. In: Proc. 1st Int. Rangeland Congress (ed. D.N. Hyder). Soc. Range Manage., Denver, Colo.

Savory, A. 1979. Range management principles underlying short duration grazing, p. 375-379. In: Beef Cattle Science Handbook, Agri-services Foundation. Clovis, Calif.

Sharp, A.L., L.J. Bond, J.W. Neuberger, A.R. Kuhlman, and J.K. Lewis. 1964. Runoff as affected by intensity of grazing on rangeland. J. Soil Water Conserv. 19:103-106.
Smeins, F.E., T.W. Taylor, and L.B. Merrill. 1976. Vegetation of a 25-year exclosure on the Edwards Plateau, Texas. J. Range Manage. 29:24-29. Snedecor, G.W., and W.G. Cochran. 1971. Statistical methods. Iowa State Univ. Press, Ames.

Thurow, T.L. 1985. Hydrologic interrelationships with vegetation and soil as affected by selected livestock grazing systems and climate on the Edwards Plateau. Ph.D. Diss. Texas A\&M Univ., College Station. (Diss. Abstr. 46:1412).

Thurow, T.L., W.H. Blackburn, and C.A. Taylor, Jr. 1986. Hydrologic characteristics of vegetation types as affected by livestock grazing systems, Edwards Plateau, Texas. J. Range Manage. 39:505-509.

Walker, B.H. 1974. Ecological considerations in the management of semiarid ecosystems in South-Central Africa, p. 124-129. Proc. Ist Int. Congr. Ecol.

Wood, M.K., and W.H. Blakeburn. 1984. Vegetation and soil responses to cattle grazing systems in the Texas rolling plains. J. Range Manage. 37:303-308. 